\title{
Evaluation of Spatial Fictions, Design Concepts, Aesthetic Quests of Traditional, Modern Mosques from Past to Present and the Analysis of Mosque Samples
}

\author{
Ş. Ebru Okuyucu \\ Department of Interior Architecture and Environmental Design, Afyon Kocatepe University, Turkey
}

Copyright $(2016$ by authors, all rights reserved. Authors agree that this article remains permanently open access under the terms of the Creative Commons Attribution License 4.0 International License

\begin{abstract}
Mosque has played a central role in Islamic society. The Prophet ordered for the construction of a mosque in Medina (Yesrib) where he arrived after hegira, thus he began to form Islamic institutions from the mosque. That's why the mosque maintained its place throughout the history as an important source for Islamic institutions. Mosques are also the spaces, as a socio - cultural element, where the social life is maintained, which are used for worship by Muslims as their primary objective, which are appropriate for individual and common worship and where they are educated religiously. Mosques have been always considered as an area of usage for people, and for achievement of these functions in a healthy manner; necessary elements of the structure should comply with users' properties and should be convenient for use. Besides being functional, further architectural features which the mosques are required to involve are that; they should meet users' aesthetic quests and should have a design concept. Evaluation criteria in architecture depend on "robustness", "suitability" and "aesthetic" concepts. In the evaluation, numerical data may be obtained. Suitability and robustness arise in the structure or building which replies people's material needs. But to consider a building as an architectural work, it should acquire "aesthetic" values and should meet psychological and socio- cultural needs of the user as well. Within this context, in the study; architectural fictions of the mosques from past to present was evaluated, thus the outdoor qualitative properties and indoor schemes of the mosques were analyzed. Totally, 10 separate mosques were evaluated in two separate categories; "Traditional and Modern". Historical mosques were defined within the scope of "Traditional Approach", whereas the structures which had been constructed by the attempt of being different by using modern material and technique within its own style and aesthetic, out of traditional concept, were defined within the scope of "Modern Approach". Based on the mosques which were analyzed due to their space fictions and qualitative properties; the mosques selected under modern and traditional classifications were analyzed. Architectural
\end{abstract}

elements involved by the mosque were grouped and these elements were discussed in terms of material, form and aesthetic. The design concepts of the mosques were made within the context of the materials and forms of indoor and outdoor spaces, whereas space fiction analysis was made within the context of covering system and plan arrangement, and the aesthetic concept analysis of the indoor space was achieved within the context of basic design principles. In line with the data obtained; differences and similarities were revealed in terms of physical compliance, design concepts, spatial fictions, ergonomics, aesthetic quests and psychological perception, and suggestions were made in this respect.

Keywords Mosque, Interior Design of Mosque, Traditional Mosque, Modern Mosque

\section{Introduction}

Mosques are the places which are suitable for worshipping and praying individually and collectively and where Muslims gather for worshipping and praying as their primary purpose, receive religious training and community life is lived as socio-cultural element. Necessary structure elements of mosques which have always been a usage area for people need to be appropriate for the user properties and should be used comfortably in order for their functions to be executed wholesomely (Y1lmaz) [21]. Mosques; according to Aydinlı [4] are categorized into two groups as "traditional mosques" which are made of traditional materials such as stone, soil and wood and "modern mosques" which are nontraditional in its own style and aesthetics and made of contemporary materials such as reinforced concrete and steel by making use of modern materials and techniques. In this study, 6 mosques which are categorized as modern and traditional are analyzed with respect to venue setup, interior accessories, materials that are used and sense of aesthetics. Traditional 
mosque samples which were evaluated within the scope of study were chosen among the ones which were constructed during the Ottoman period and westernization period while the modern mosque samples were chosen among today's mosques and their venue setups were evaluated. Formal features of mihrabs (niche of a mosque indicating the direction of Mecca) and minbar as the interior accessories of mosques were analyzed while only formal features of minarets as the outer accessories of the mosques were analyzed.

\subsection{Elements of Mosques and Their Formal Features}

Functional requirements such as calling the faithful and believers to the mosque for prayer, briefly thecall to prayer (adhan), a high place to recite the adhan (minaret), fountains for cleansing ritual called wudu of the people who came to mosque to pray (sadirvan), an open or closed place as prayer hall big enough for the people to form and stand in a row, a niche where the imam can stand in front of the congregation (mihrab), a raised platform where various speeches are made (minbar) are the basic data which structured the mosque place (Ödekan,) [16]. It is possible to show the traditional parts of a medium scaled mosque and their approximate places in Turkish architecture like the following:

Mihrab: The niche in the qibla wall of a mosque is called mihrab and it is used by imam to stand in front of the congregation while praying. Another point that could be focused with respect to the mihrabs-structure relation is that mihrab overhangs interior or outer surface of the wall and this is related with the structure and material of the mihrabs. Deep mihrabs are sticking out in the wall mass (Tümer) [20]. Internal protruding mihrabs are the examples for which different materials, other than the ones used in the wall such as glazed tiles and plaster, are used. Wall surface continues uninterruptedly in the structures of which mihrab is cut stone as the interior wall is covered with the same material. It is natural that stones which are the main equipment in Anatolia especially for the monumental architecture are used in the mihrabs. In addition to the cut stones, the most frequent material used for the mihrabs is faience mosaic. When the mihrabs are analyzed with respect to their structures, shapes and the elements they have, it can be understood that most of the mihrabs in Anatolia are limited with rectangle frames. Rectangular, polygonal or semicircle mihrabs with muqarnas, but without arch form the biggest group among the mihrabs with corner bead, pediment and edgings. The second group is the arched mihrabs which stand on columns. Mihrab niche which is framed with semicircle, four-centered, cusped, drop arches is generally covered with kavsara. The materials used for the mihrabs are stones, plaster, glazed tiles and woods and a certain decoration program was applied; geometrical and vegetative compositions, writing strips and muqarnas cover a certain area; geometric and vegetative motifs, sometimes muqarnas and writings ornament the edge strips which frame the niches; writing strips with inscriptions are located either on the corner bead plate or on the area which separates the kavsara and underside of the niche (Ödekan,) [16].

Nave: It is the place reserved for praying in a mosque as the prayer hall.

Harem: It is the inner court of Ottoman mosques where there is an ablution fountain in the middle.

Harim (sanctum sanctorum): It is the outer court sided by fortified walls which separates the Ottoman mosques from the surrounding houses and streets.

Portico: It is the covered, frontally open arcade or gallery.

Ablution fountain: It is a structure which is surrounded by walls with taps or a pool from which abundant water falls and it is the place where people perform a ritual cleansing before entering the mosque for prayer.

Minbar: It is the mosque element which has a staircase leading to the top platform sometimes covered by a dome. It is used by the speaker or the prayer leader (imam) to deliver sermons (khutbah). The early minbar samples were constructed by wooden materials. When it comes to the position of the early minbar samples in the mosques, it is seen that they are located in front of the qibla wall and on the right of the mihrab in accordance with the function and mission requirements that this architectural element has. Minbars have a very significant place in the Islamic belief, culture and tradition. It is a pretty obvious fact that minbars had a function and a mission beyond the worship during the early period İslam mosque architecture (Erengezgin) [8].

Royal loge (Hünkar Mahfil): It is the raised and barred place which has a special gate and staircase separated for sultans to pray and worship in Ottoman mosques.

Muezzin's Mahfil: It is a platform opposite the minbar where the assistant of the Imam, the muezzin, stands during prayer to repeat the takbirs of the imam to the congregation who are in the back rows. The muezzin recites the answers to the prayers of the Imam where applicable.

Women's Mahfil: It is the section separated for the women to be used during prayer which is generally located in the top floor of the mosque.

Minaret: It is a high and slim tower where the call to prayer is announced by the muezzin. It is thought that the first minarets were originated from the church campaniles or constructed by taking bell towers, lighthouses and other similar towers as examples. However; no matter what the first source of inspiration is, it is known that minaret elements shaped as the most rational way to make the call to prayer heard by much more people or further do not have the same formal features in every place of the Islamic World (Diez) [7]. At the vertical separation of the mosques throughout the Ottoman period, minarets were constructed in conformity with the weight towers and the separation in the groundmass along with the raising of the minaret balconies in order made a perfect harmony. It can also be seen that this vertical separation in the mosque mass also complies with the minarets and weight towers. Narrowing down of the main venue mass upwardly is exactly reflected in the minaret form as base, shaft and a gallery. The ratio between the minaret and size and height of the structure was thought carefully; 
therefore, this architectural element created opinion of a higher building encircling it instead of downsizing the main building (Ülgen) [19].

\subsection{Development of the Traditional Mosque Venue Setup}

Since the historical processes of all mosques could not be scrutinized, only mosque samples from the Ottoman period were handled. The central dome of the classical period mosques is the dominant element of the interior architecture. The other elements such as prayer Mahfil (hall), Royal loge (Hünkar Mahfil), Muezzin's Mahfil etc. are located in the sides or next to the back wall of the mosque in a way that they will not break the monumental character of this dome. Prayer halls (the worshipping areas) were thought with the aim of increasing the capacity of the mosque (Akok) [2]. The mosque type which was given priority during the early periods of Ottoman architecture was the subline-angled mosques. Then, the idea of creating a single and big space emerged; therefore, the mosque plan scheme made a big progress by increasing the diameter of the domes along with adding auxiliary units which support them. Gathering under the dome was aimed with central planned scheme (Kuban) [13]. The dome is the most significant element similar to the work done in the previous periods. Gathering the inner space under the dome on the one hand symbolizes the oneness, on the other hand it symbolizes the central structure of the Ottoman Empire. In addition, the space integrity that the central plan provided made it possible to construct higher mosques. The most spectacular examples of central planned mosques were given in the Classical Ottoman architecture period and Sinan the Architect played the most significant role in this success. When the single dome was inadequate for the big mosques of the Ottoman Architecture, interior area of the mosque was increased by supporting the base unit dome with the secondary element which was basically the semi-domes (Kuran) [15]. The mosque plan scheme has developed for centuries and the Ottomans took a step further in terms of both plan and architectural features in its Classical period. We can see the mosque architecture with central dome, inner and outer court with portico where the unity between the inner area and outer area was obtained, simplicity was not neglected, monumental however modest. The progress which was made by the traditional organization in the mosque plan scheme until the $18^{\text {th }}$ century, did not developed in this century; Closeness with the West, France being in the first place, along with the adopted new style were applied on the classical Ottoman mosques as supplementary. European rococo and baroque arts were applied to the architecture by the European artists during this period which is called Turkish baroque. Acanthus leaves, clam motifs, cartridges and many other new motifs were used instead of the classical Ottoman architecture decorations and these classic details never came back. As a result of this astonishing change, domes with muqarnas, lancet arches, and straight lines gave way to western structures. Galleries were constructed at the two sides and mihrabs were constructed as a cell in order to provide wideness to the mosque area. The biggest change of this century is the north façade apart from the prayer hall. The narthex, minarets and the royal loge (Hünkar Mahfil) were integrated in the north façade. This scheme always developed until the end of the $19^{\text {th }}$ century. Moreover, façades were fragmented, domes were enhanced, slim corner towers were constructed, minarets were narrowed with the arrangements in the dimensions of the windows on the surfaces and new oval, round window forms along with the ornaments taken from the west; therefore, a sense of height was wanted to be created. High staircases at the entrance of the mosques were built with the monumentality affect. At the end of the century, rectangular courts with fountain and portico were left and outer courts were preferred instead (İnci) [11]

\section{Traditional Mosque Examples}

Design concept analysis of the mosques were made in terms of forms and materials of fitting sin inner and outer spaces, venue setup analysis were made in terms of coverage system and plan arrangement, aesthetic understanding analysis of the inner space design were made in accordance with the basic design principles. "Süleymaniye Mosque", "Nuruosmaniye Mosque" and "Ortaköy Mosque" were chosen as the traditional mosque examples. The reason why Suleymaniye Mosque was chosen is that it is the first structure constructed by Sinan the Architect which has two semi-domes. Sinan the Architect describes this structure as "a work of his apprenticeship period". The reason why Nuruosmaniye Mosque was chosen is that it is the first significant work which shows the influence of the Baroque and Rococo art. The reason why Ortaköy Mosque was chosen is that it was built in neo-baroque and empire style and its fragmented façade emphasis. Another reason is that venue setups, façade arrangements and ornament elements which contribute the sense of aesthetic of the three mosques are different with respect to the plan scheme.

\subsection{Süleymaniye Mosque}

Sinan the Architect designed Süleymaniye Mosque as a large scale mosque symbolizing the power of the sultan which was constructed by Suleyman the Magnificent on his behalf between the years of 1550-1557. Sinan the Architect after Şehzade Mosque and the other structures returned to two semi-domes plan scheme with the Süleymaniye Mosque. It can be seen that the mosque which consists of one big dome in the middle, semi-domes at two sides and small domes of different dimensions also contained old assimilations. A more powerful inner space was created in Suleymaniye Mosque of which measures are similar to Haghia Sophia by using the technology of its own period. At the same time, the inner space was thought together with the outer mass effect (Özer) [18]. The big dome in Suleymaniye 
which Sinan the Architect described as "the work of his apprenticeship period" was situated on four big carrier columns and supported by two semi-domes in the directions of the entrance and mihrab. Semi-domes were extended by quarter domes. Side sections were covered with five domes; however, a different effect was created with one big one small dome (a-b-a-b-a) rhythm instead of monotony of the equal domes. Therefore, the dome which is in the middle has the same wideness with the domes in the corner and side sections were integrated with the inner space. Consequently, spaciousness and wideness effect were created in the inner space (Çamlıbel) [5]. Similarly, the monumental courtyard was handled with a sense of unity with the minarets which were organically integrated with the structure. Pyramidal appearance was provided in the best way with the integration of the minarets in the structure. Two of the four minarets were located in the courtyard corners and they have one gallery, the other two minarets were located in the mosque mass corner and they have three galleries. The inner space structure of the mosque was reflected in the outer appearance with its all details (Aslanapa) [3]. (Table1.)

Table 1. Suleymaniye Mosque Analysis

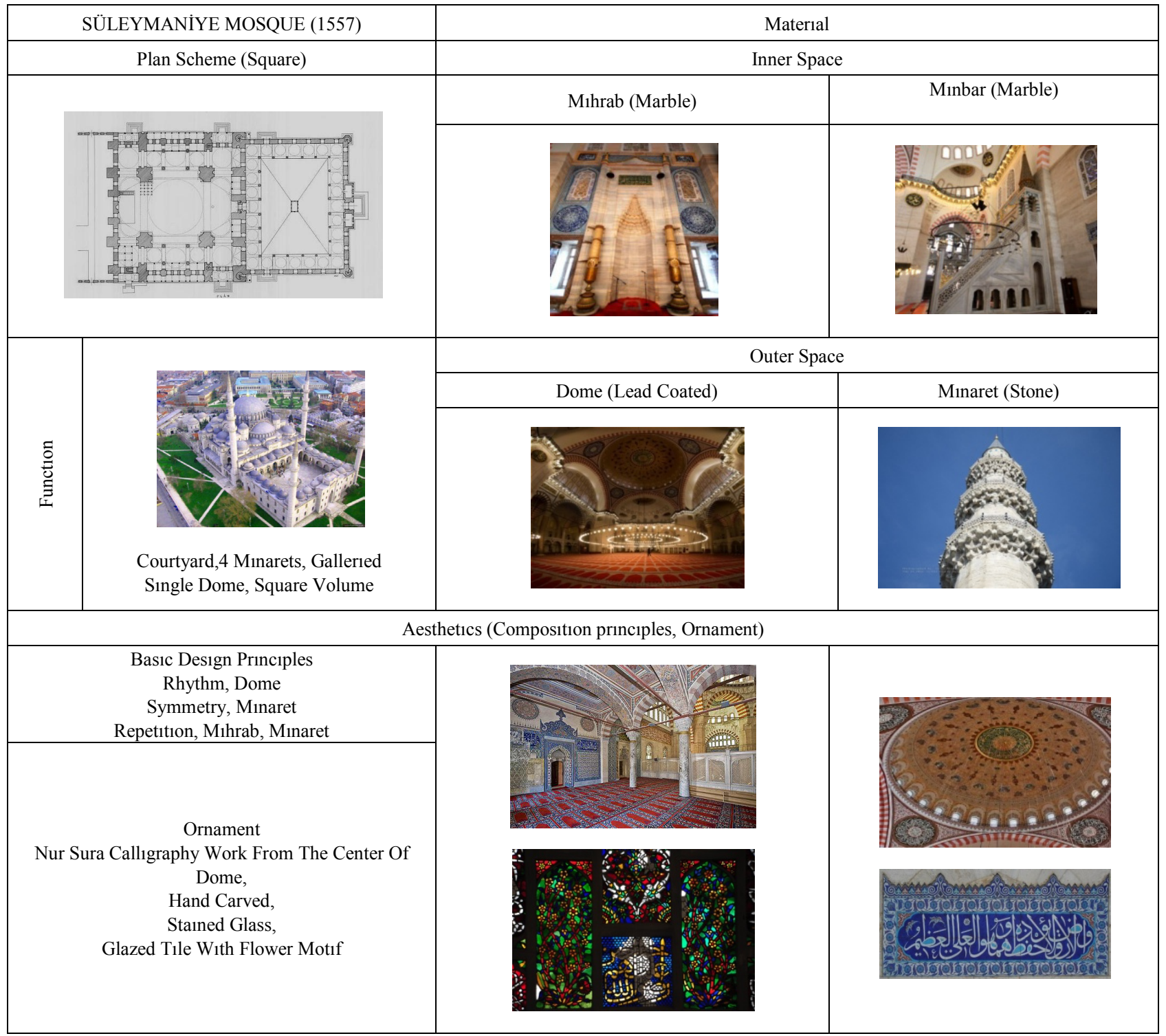


Table 2. Nur-u Osmaniye Mosque Analysis

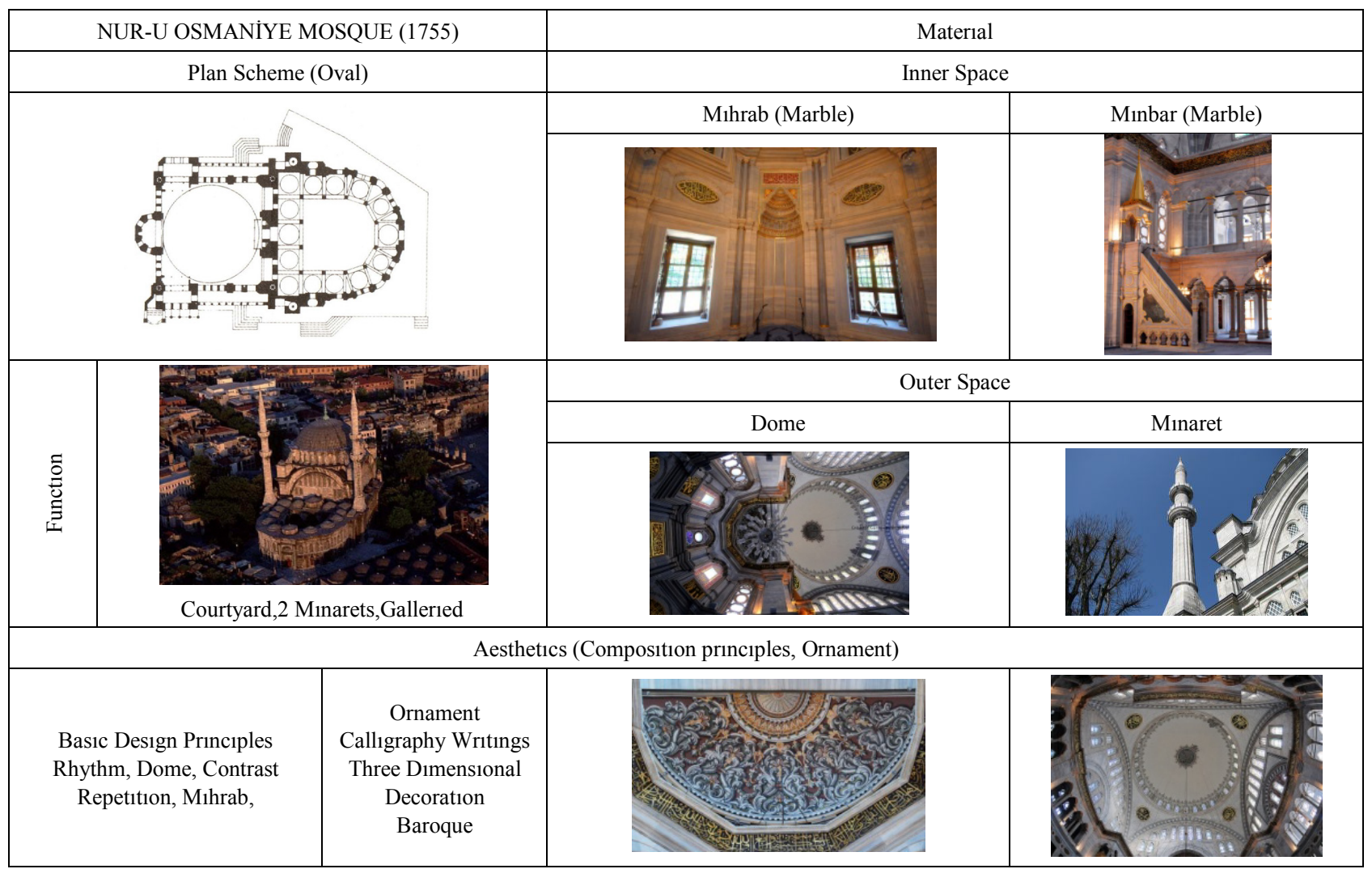

\subsection{Nur-u Osmaniye Mosque}

The mosque which was constructed between the years of 1748-1755 is an example of Tulip Period works. The mosque is the first big work which shows the Baroque and Rococo art effects. Dome of the mosque which is 27.75 meter in diameter is situated on four big arches. Mihrab section juts out which is covered with a semi-dome. Mihrab, Minbar and molding of the mosque were made in Baroque style artistically. The writings of the mosque belong to the well-known calligraphers (Öz) [17]. Abundance of the ornaments draws the attention. Sea shells, wavy arches and various column headings and weight towers are the first examples of Turkish Baroque style. While wavy arches, sea shells, acanthus leafs became frequently used motifs, arch forms show up with change of directions on the walls, asymmetric arrangements of the plasters which were put in the inter sections other than the "S" and "C" folding. Mihrab section has a polygonal plan which is covered with a small and low semi-dome jutting out unlike the usual style in Ottoman mosque architecture. There are minarets with baroque stone cone and two galleries where the court with portico and mosque unite. Mihrab inner venue setup is different from the single domed mosques. It is relatively low and does not have galleries. Galleries surrounding the sanctuary are like continuous loges located at high points.
The porticos under them stand in the main volume compared to other mosques. (Table 2.)

\subsection{Ortaköy Mosque}

Mosque main space is square planned and covered with dome. Main outer wall goes until the hanger arches and sits on the corner columns. Grooved, round, fluted columns which are situated in the façades can also be felt inside. Pendants go down through the hanger arches and integrate with contre-poid towers which are situated on the corner columns. Stone façades of the mosque have ornaments with carvings and embossments which are in baroque style. The inner space of the mosque which is enlightened with big windows is enriched with hand-carved, stucco, plaster profiles and golden foil ornaments. Moreover, there are porphyroid mihrab, minbar and pulpit in this space. The mosque known with its slim and elegant minaret was built in a complex style. It is single domed and exterior surface of the pendentives between the dome and the corners where retaining arches unite are covered with lead. Ortaköy Mosque like all the other sultan mosques of $19^{\text {th }}$ century contains two sections. It is composed of a Harim (sanctum sanctorum) and a Hünkar Kasrı (sultan's summer palace). Both of the two sections are symmetric except for the hünkar entrance and equal to each other (Akar) [1]. (Table 3). 
Table 3. Ortaköy Mosque Analysis

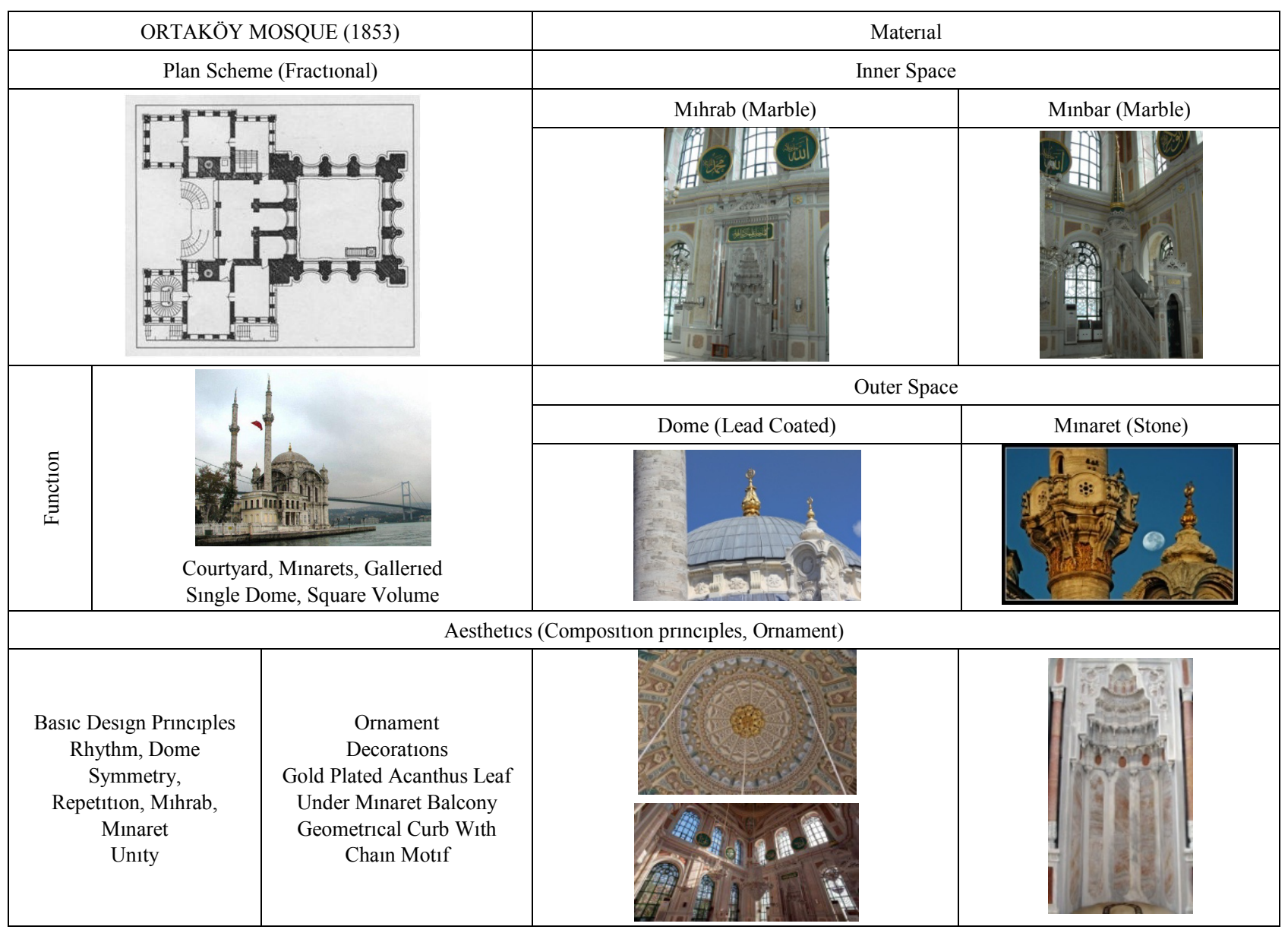

\section{The Modern Mosques}

The examples of modern mosque designs show different typologies in terms of architectural features. The main principle of modern mosque approach is based on the principle which the mosques are built in their own styles and aesthetics except the conventional styles (Holod, Khan) [10]. Therefore; the modernity which arises from using modern materials lead by only modern technology is not adequate, the modernity in designs is also required. The quality of the mosques which have been built in Turkey in the last 50 years creates one of the most significant problems of modern Turkish architecture and emulation to the architectural styles of the last centuries comes into prominence as the common characteristics of more than seventy thousand mosques which are the works of this period. Since 1960's, even if the first unique examples of modern mosque designs in different cities of Anatolia particularly in İstanbul have been known to be constructed, unfortunately; the researches indicate that the number of this kind of mosques does not reach a hundred all around Turkey. It is known that the first mosques are not dome-shaped constructs. The fixed components of the mosque architecture comprise of a mihrab which determines the direction of through which side people will pray; a minbar and a pulpit where sermons are preached; and finally a minaret which is used for informing people about prayer times. The dome is not basically a symbolic but a functional architectural component. It was used as the most advantageous way of covering a wide building throughout history before the Industrial Revolution. After the $19^{\text {th }}$ century, its function mostly comes to the end with the development of steel and reinforced concrete. The dome, thanks to the symbolic meaning assigned and current constructors, becomes the "irreplaceable" component of the $20^{\text {th }}$ century mosque architecture. The similarities between the first mosques and current day mosques of Islam Religion are significantly low. Since the first periods of Islam, the mosque architecture has constantly developed and appearances of the mosques have changed to a large extent according to the characteristics of the various geographies where Islam has spread. Therefore; the mosque architecture is not a concept which only comprised of irreplaceable components, but it does not include formalist expectations, either. None of the mosques was the replica of other mosques in the past and each of the new mosques had an innovation, a new style and a technological development.

It is possible to examine these mosques under three main titles according to their qualifications: 
a. Curvilinear top covered mosques

b. Dished plate/ pyramidal top covered mosques

c. Form and Mass Trials

a. Curvilinear top covered mosques: Curvilinear top covered mosques constitute the most crowded group within the contemporary mosques which could be detected. The reason of this case is that the architects and especially the society still think that the dome-shaped mosques are anyway more acceptable. In the interviews with the architects, it is mostly pointed out that the employers force and insist heavily on their desires for the mosque to be constructed in dome shape. It is considered that the architectures follow two ways under this attitude of the employers. The first way is building a new mosque again by using the reinforced concrete technology choosing from one or more examples of the highly appreciated Ottoman period mosques, and the other one is adding the contemporary interpretations along with including a dome while preparing the design of the mosque. It is not possible to say that the second approach, which is highly difficult, always leads to aesthetic results. There are some examples which show that dome architecture is highly influenced by the $20^{\text {th }}$ century developments with ingenious solutions.

b. Dished plate/ pyramidal top covered mosques: Dished plate/ pyramidal top covered mosques constitute the group which includes the examples of the contemporary comments of central space tradition of Ottoman architecture. While these mosques present a highly different outlook than the image of "Ottoman mosques", they are also the constructs which bring central space understanding in the Classical Ottoman mosques successfully to the present.

c. Form and Mass Trials: The mosques, which arouse the dome or dome effect and do not use the dished plate/ pyramidal top covered system, are considered in this group. One of the mosques which is included in this group and widely known is TBMM (Turkish Grand National Assembly) Mosque which was designed by Behruz and Can Çinici (1989). Its plan has a rectangular sanctuary of which long side is parallel to mihrab wall, a conic upper cover which was constructed through cascading and rising of the reinforced concrete beams through the mihrab (Eyüpgiller) [9].

\subsection{TBMM (Turkish Grand National Assembly) Mosque}

Table 4. TBMM Mosque Analysis

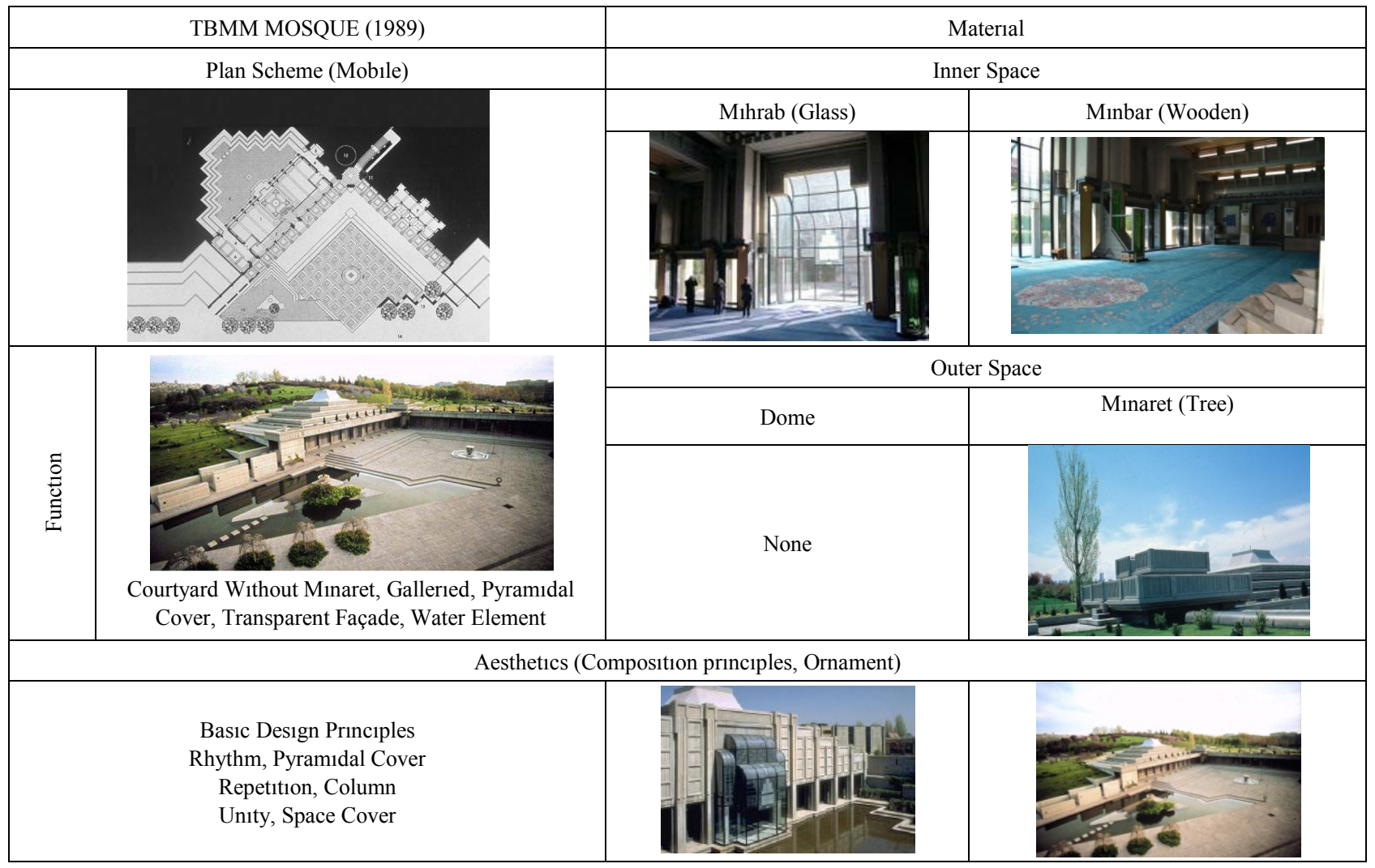


The mosque which is designed by Behruz Çinici and Can Çinici and located in the TBMM complex is a modest structure which is deliberately free from monumentality. A new design was suggested in the mosque architecture. The mosque of which construction started in 1985 was located in the assembly complex which is in the north south direction. The structure which was positioned by 23 degree deviation from the centerline in order to front to the qibla a circulation distribution point was created (Çinici) [6]. The mosque which is in south north direction consists of three main sections. These are the garden which is under the ground level, rectangular shaped harim and triangular forecourt which is in north. The forecourt was surrounded by porticos. Additionally, there is a bookcase in the mosque which does not have a minaret. Harim is covered with a fractional pyramid. Natural light enters into the inner space from the girders that constitute the pyramid. Mihrab is a completely transparent niche which is embodied to the ground, facing the garden and containing a pool in it. The mosque was affected by the early İslamic architecture. The minaret of the mosque which has a structure free from the monumentality was symbolized with a cypress tree. Qibla wall opening to a garden with pool is transparent unlike the understanding of our day. This garden which is in the south direction refers to İslamic garden which is described as a heaven metaphor by the researchers (Çinici) [6]. (Table 4).

\subsection{Yeşilvadi Mosque}

Yeşilvadi mosque was built in 2010 and the architect of the mosque is Adnan Kazmaoğlu. Yeşilvadi mosque stylistically, with its circular plan which was applied to prayer hall (worshipping area) for the first time, curvatures emerged on the surface depending on the plan, hemisphere form as mass, length of the minarets because gnomon was wanted to be created, different designs of sherefes (minaret balconies) and cones which are full of figurativeness, glass usage different from the traditional although they were tried for mihrab and minbar before in the inner space, using gilded calligraphies instead of ornaments, again using mostly the cufic calligraphies which is the preference of the recent years is a new design unlike the mosques built in the past. However, the mosque still refers to the past by the usage of a dome and a minaret no matter how different the form is. When the mosque is analyzed with respect to its structure, it can be seen that it was constructed with reinforced concrete system which is the common technology of its era. When it comes to the material usage, it is completely covered with marble. The idea of obtaining a plain white appearance and creating a modern style by using marble was also applied for the inner space. The integrity and unity were wanted to be created by using marble for inner space components and details even for the shoe cabinets. Glass was used as the supplementary material. Another remarkable point in the mosque is that all this material and form seeking was considered over an intense symbolism. There are different religious interpretations in almost every detail of the mosque (Kazmaoğlu)[12].(Table5).

Table 5. Yeşilvadi Mosque Analysis

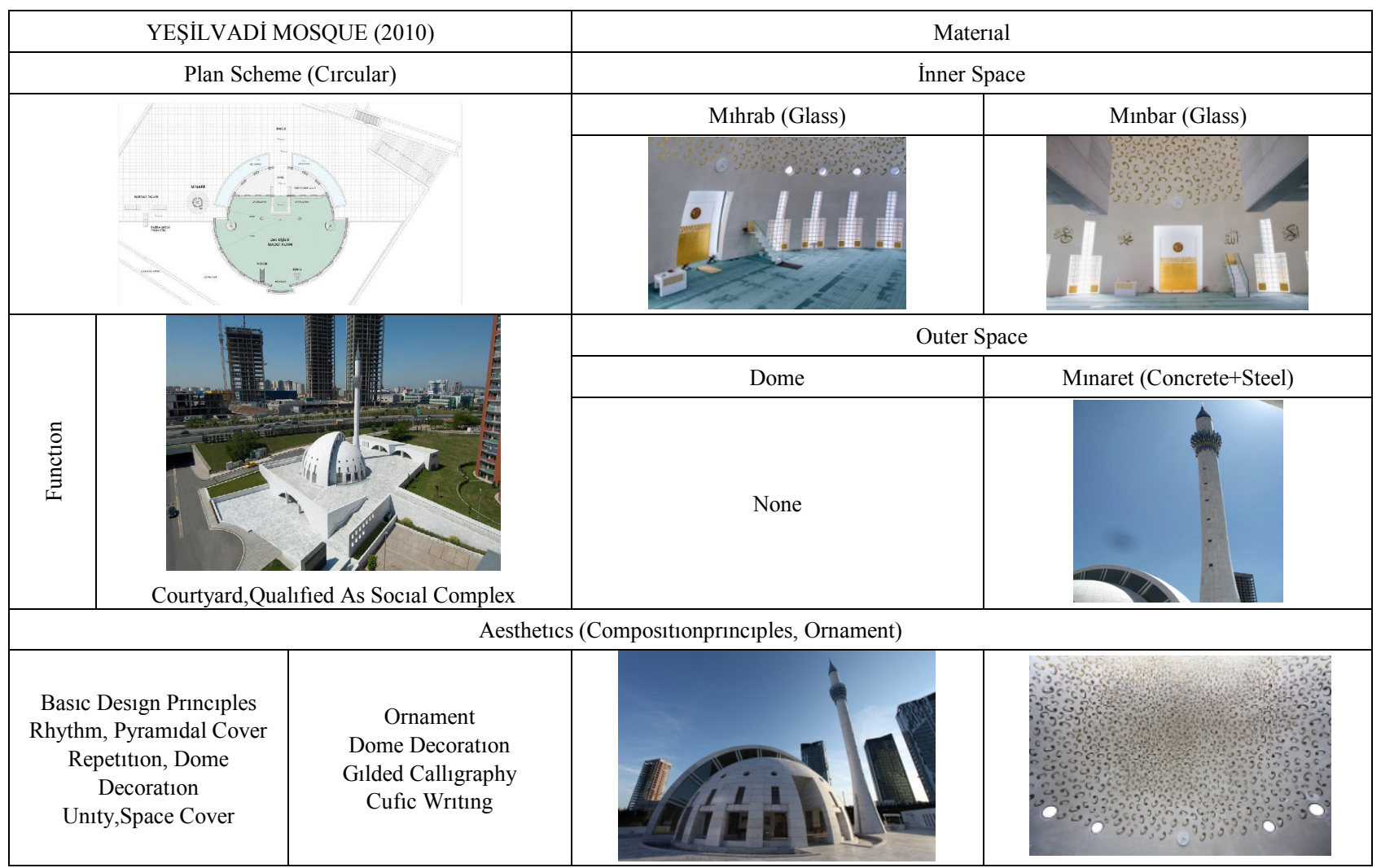




\section{3. Şakirin Mosque}

The mosque was designed by Hüsrev Tayla and Zeynep Fadıllioğlu in 2010. The main mass of the mosque seems as if it was made of shell when it is looked from the outside; however, inner space unity provided by this shell was broken with columns and beams. The façades of the mosque were closed with aluminum units and nonfunctional big spaces were created between these units and the surface of the inner space which was restricted with columns and beams. The dome of the mosque was covered with aluminum composite. Porticos of the court are not arched. Porticos were created with the repetition of the reinforced concrete beam and columns and the top cover is not a complete dome. In addition, an ablution fountain was not made in the middle of the porticos. William Pye, a well-known water sculptor, designed a small pool as a transparent dome. Minarets are located in the two sides of the mosque at the level of narthex separated from the main mass. Moreover, minarets were made slimmer compared to the mosque mass (Kuban) [14]. The mihrab seems like a green circular niche. The inner side was painted with gold bronze powder. The width of the mihrab covers three rows and it was raised one elevation from the mosque harem. Minbar is on the right side of the mihrab and it was designed out of the classic minbar forms. The minbar consists of twelve steps which have circular lines made of fiber materials and its color is light brown (fallow). Glass surfaces on the façades were completely covered with gilded wavy shapes. Red color was used in the mosque and the dome (Table 6).

Table 6. Şakirin Mosque Analysis

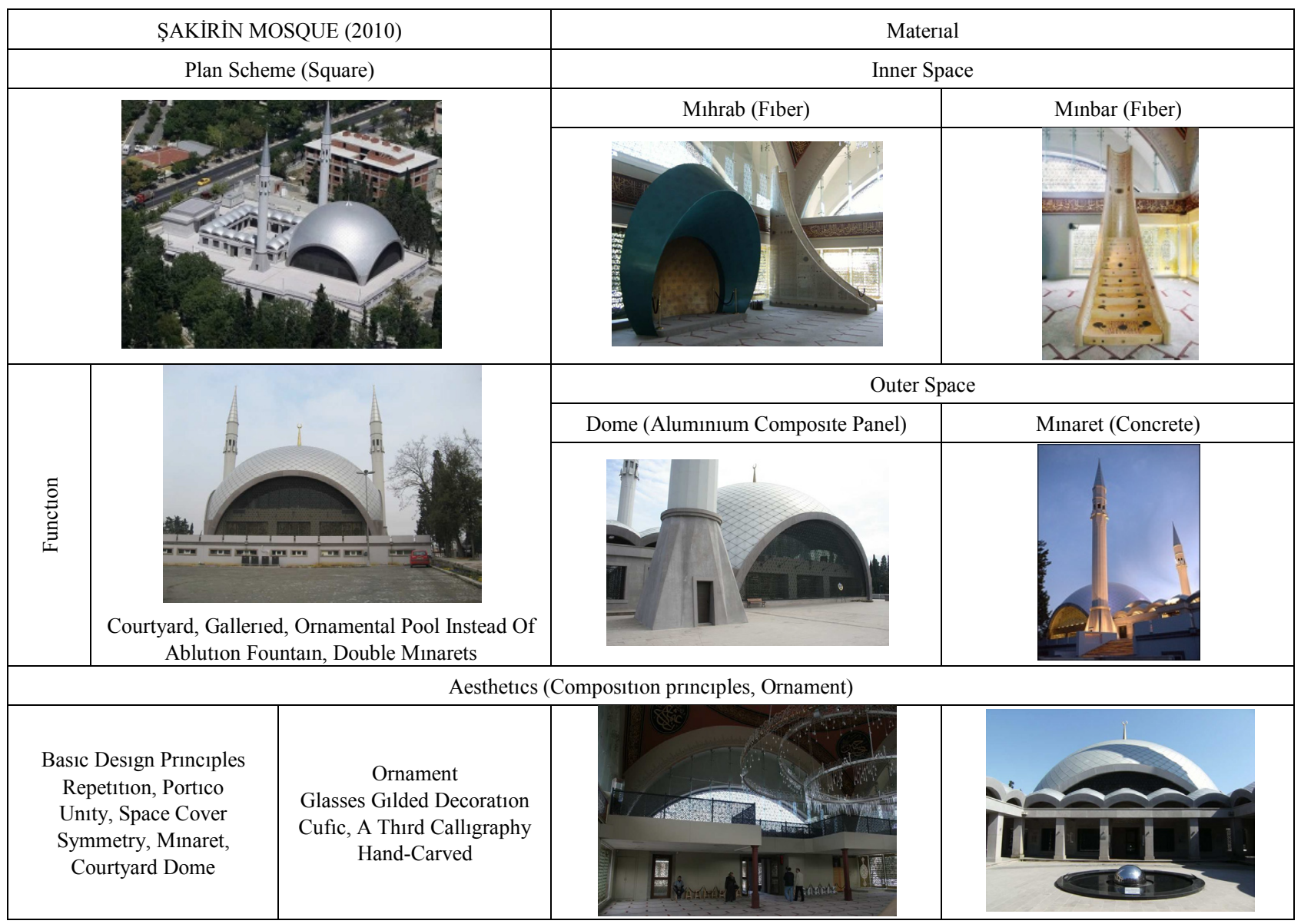




\section{Results}

100 people chosen among the Faculty of Fine Arts students and instructors were asked questions related to inner space and design concept of the mosques, mosque elements (mihrab, minbar, minarets) aesthetics, ornamentation and design philosophy in conformity with the sense of mosque in company with the picture slides of the mosques for the analysis of sense of aesthetic of the mosques. 100 people were grouped according to 18-25 age range and 25-40 age range. The questions which were asked were graded from 1 to 5 ( 5 being the highest point and 1 being the lowest point).(Figure 1.)

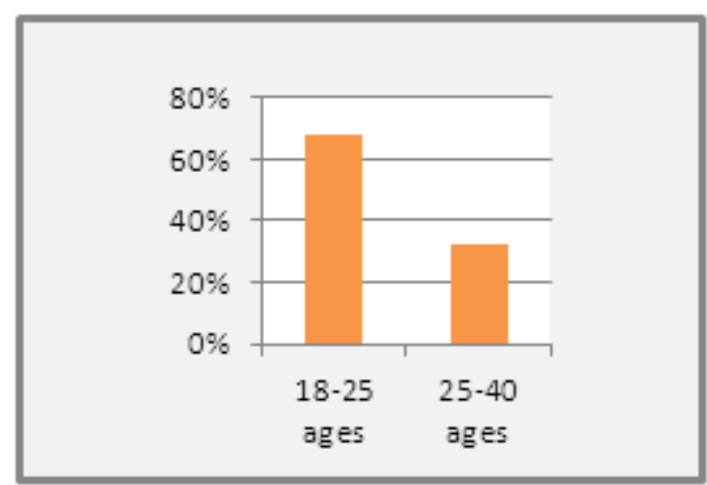

Figure 1.

Students of Department of Interior Design were created 18-25 age range and teaching staff of Fine Arts Faculty were created 25-40 age range of 100 participants.

Table 7. Evaluation of the Sense of Aesthetics of the Mosques

\begin{tabular}{|c|c|c|c|c|c|}
\hline MOSQUES & $\begin{array}{c}\text { DESIGN } \\
\text { CONCEPT }\end{array}$ & $\begin{array}{c}\text { INNER } \\
\text { SPACE }\end{array}$ & $\begin{array}{c}\text { MIHRAB,MINBAR,MIN } \\
\text { ARET }\end{array}$ & $\begin{array}{c}\text { MOSQUE DESIGN } \\
\text { UNDERSTANDING }\end{array}$ & AESTHETIC \\
\hline SÜLEYMANIYE & 4,88 & 4,84 & 4,66 & 4,82 & 4,51 \\
\hline NUR-U OSMANIYE & 4,09 & 4,01 & 4,00 & 4,37 & 4,24 \\
\hline ORTAKÖY & 4,09 & 4,19 & 4,21 & 3,84 & 3,45 \\
\hline TBMM & 3,17 & 2,94 & 2,76 & 2,07 & 3,75 \\
\hline YEŞILVADİ & 3,94 & 3,37 & 3,19 & 2,98 & 4,09 \\
\hline ŞAKIRIN & 3,56 & 3,39 & 3,39 & 2,80 & \\
\hline
\end{tabular}

It was seen in the analysis conducted according to results of answers of 100 participants that design concepts, conformability to mosque conception and perception of aesthetics of traditional mosques are higher than modern mosques'. This indicates that classical Ottoman period mosque conception in traditional mosques obviates all modern designs. One of the survey questions was "Is there any Islamic symbol in modern mosques?" Analysis of answers is given below (Table 8). Data of survey results obtained when participant are categorized according to their age ranges are shown in diagram (Figure 2-3).

Table 8. Symbol of Religion in Mosque

\begin{tabular}{|c|c|c|}
\hline MOSQUES & SYMBOL OF RELIGION & RATE \\
\hline ŞAKİRIN MOSQUE & MINARET & $\% 74$ \\
\hline YEŞILVADİ MOSQUE & "و "CHARACTER AT INNER SPACE & $\% 97$ \\
\hline TBMM MOSQUE & MINARET & $\% 92$ \\
\hline
\end{tabular}

When survey results are analyzed it can be seen that the mosque element which is perceived as symbol in Şakirin Mosque is minaret. In Şakirin Mosque minaret functions only in a symbolic manner. Properties such as lack of minaret balcony in the minaret, having some other parts on the minaret instead of minaret balcony which is made of another material and resembling the minaret balcony, minarets being away from main mosque campus indicate that minaret functions only in a symbolic manner. The symbol used for Yeşilvadi Mosque is the letter \& which is very important for Islam. Islam Religion is symbolized by using this symbol on every interior walls and ceilings. The symbol for TBMM (Grant National Assembly of Turkey) Mosque is the minaret and in the mosque a poplar tree is planted instead of a minaret. Poplar tree refers to the minaret. 


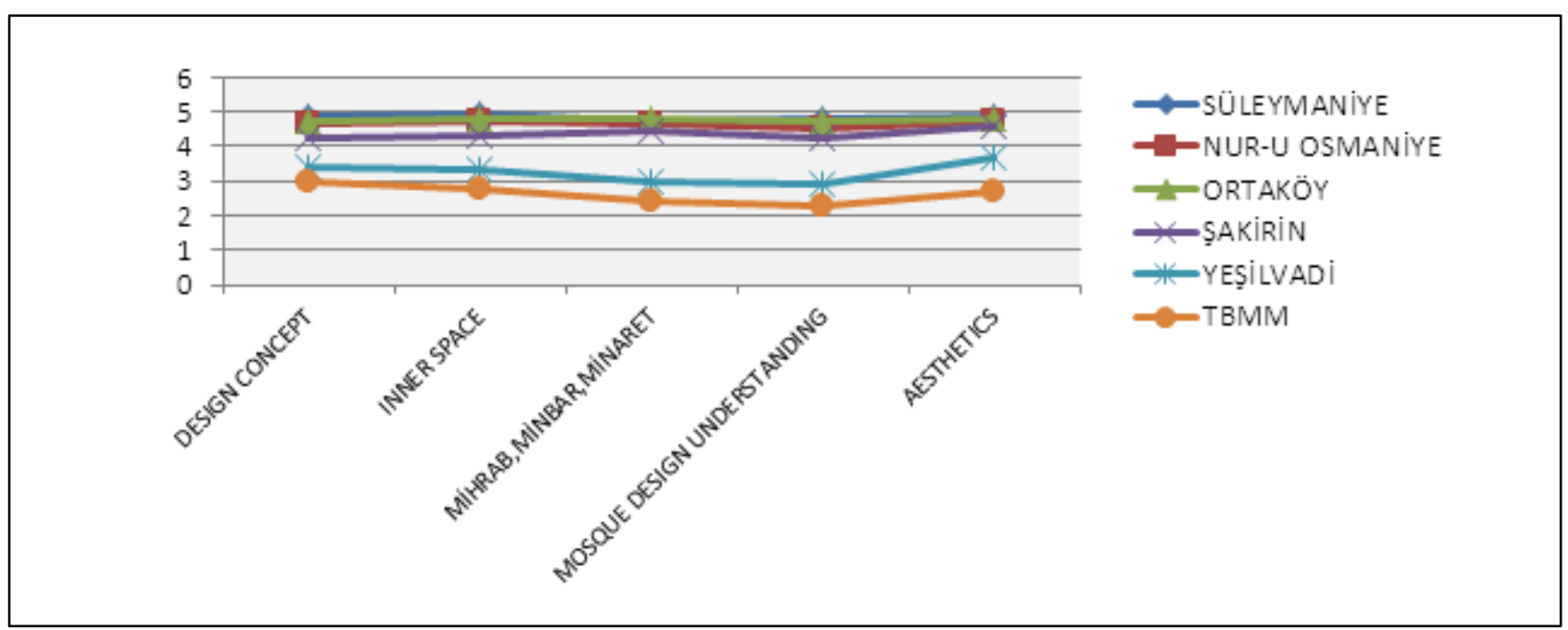

Figure 2. Criticism of mosque of participants at 25-40 age range

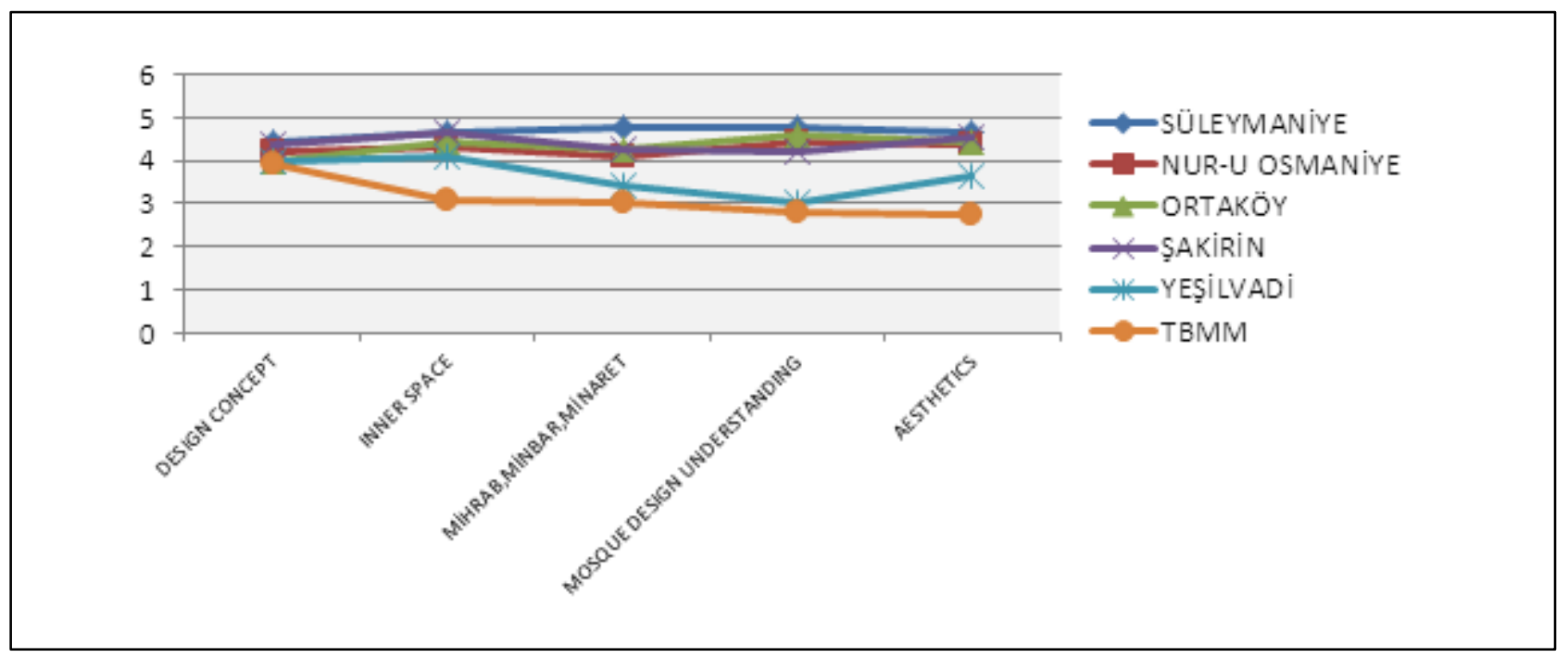

Figure 3. Criticism of mosque of participants at 18- 25 age range

When survey results of participant between ages of 18-25 are analyzed it can be seen that even though positive perceptions regarding modern mosques are higher in proportion to answers of participants between ages of 25-40, conformability to mosque conception and perception of aesthetics of traditional mosques are higher in proportion to modern mosques. When survey results of participant between ages of 25-40 are analyzed it can be seen that positive perceptions regarding traditional mosques are much higher positive perceptions regarding modern mosques. Şakirin Mosque embraces both traditional mosque conception and traditional mosque design perception in both categories.

Plan schemes of the mosques which were chosen within the scope of study along with the venue setups, formal features of the mosque elements and the basic design principles used in the inner space design were analyzed and tabulated. The results which were obtained from the tables related to the spatial features of the mosques are like the following:(Table 9) 
Table 9. General Analysis of the Mosques

\begin{tabular}{|c|c|c|c|c|c|c|c|c|c|c|}
\hline \multirow{8}{*}{ 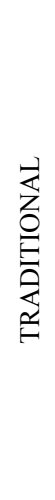 } & \multirow{2}{*}{$\begin{array}{l}\text { NAME OF } \\
\text { THE } \\
\text { MOSQUE }\end{array}$} & \multirow{2}{*}{$\begin{array}{c}\text { PLAN } \\
\text { SCHEME }\end{array}$} & \multicolumn{3}{|c|}{ MATERIAL- ORNAMENT } & \multicolumn{5}{|c|}{ BASIC DESIGN PRINCIPLES } \\
\hline & & & Mihrab & Minbar & Minaret & Repetition & Rhythm & Symmetry & Unity & Contrast \\
\hline & \multirow[b]{2}{*}{ Süleymaniye } & \multirow[b]{2}{*}{ Square } & Marble & Marble & Stone & & & & & \\
\hline & & & \multicolumn{3}{|c|}{$\begin{array}{l}\text { Hand carved - Stained Glass- } \\
\text { Glazed Tile- Calligraphy }\end{array}$} & & & & & \\
\hline & \multirow{2}{*}{$\begin{array}{c}\text { Nur-u } \\
\text { Osmaniye }\end{array}$} & \multirow[b]{2}{*}{ Oval } & Marble & Marble & Stone & & & & & \\
\hline & & & \multicolumn{3}{|c|}{ Calligraphy- Decoration } & & & & & \\
\hline & \multirow[b]{2}{*}{ Ortaköy } & \multirow[b]{2}{*}{ Fractional } & Marble & Marble & Stone & & & & & \\
\hline & & & \multicolumn{3}{|c|}{ Ornament-Calligraphy } & & & & & \\
\hline \multirow{6}{*}{$\begin{array}{l}\frac{Z}{\alpha} \\
\frac{1}{1} \\
\frac{0}{2}\end{array}$} & \multirow{2}{*}{ TBMM } & \multirow{2}{*}{ Mobile } & Glass & Wooden & Tree & & & & & \\
\hline & & & \multicolumn{3}{|c|}{ Landscaping-Plain } & & & & & \\
\hline & \multirow{2}{*}{ Yeşilvadi } & \multirow{2}{*}{ Oval } & Glass & Glass & $\begin{array}{c}\text { Concrete } \\
+ \text { Steel } \\
\end{array}$ & & & & & \\
\hline & & & \multicolumn{3}{|c|}{ Calligraphy- Cufic } & & & & & \\
\hline & \multirow[b]{2}{*}{ Şakirin } & \multirow[b]{2}{*}{ Square } & Fiber & Fiber & Concrete & & & & & \\
\hline & & & Decor & $\begin{array}{l}\text { a-Cufic-C } \\
\text { Iand carv }\end{array}$ & igraphy- & & & & & \\
\hline
\end{tabular}

\section{Conclusions}

Mosques especially with different plan schemes were chosen within the scope of the study.

Materials used in the mihrab, minbar and minaret which are the elements of traditional mosques are the same. From this point of view, it was seen that mostly marble and stone materials were used.

Ornaments of the traditional mosques are close to each other and it could be seen that they are generally hand-carved, calligraphy and glazed tile.

When the basic design principles used in the traditional mosques are analyzed; it could be seen that repetition, rhythm, symmetry principles are dominant. Contrast principle was used in Nur-u Osmaniye Mosque because of the plan scheme.

Plan schemes used in traditional mosques are different from each other and different designs were tried.

Materials used in the elements of modern mosques are not traditional materials and technologic materials such as glass, fiber, concrete and steel were tried.

Although the ornaments used in the modern mosques are parallel to the traditional mosques, a plainer design was seen.

TBMM Mosque focused on the landscaping elements with a very different sense of design excluding the ornaments.

The basic design principles used in the modern mosques are repetition, rhythm and unity. However, Şakirin Mosque unlike the other mosques made a reference to traditional mosques by using the symmetry principles.

When the sense of aesthetics of the mosques is analyzed; it could be seen that traditional mosques are more positive with respect to the exterior wall, space design and ornamentation.
Especially, values of Suleymaniye Mosque are very high which shows that magnificent and sumptuous traditional mosques are perceived as more positive.

When the modern mosques are analyzed; sense of aesthetics of Şakirin Mosque are higher compared to the other modern mosques which stems from the fact that Şakirin Mosque makes reference to the traditional mosque plan scheme and ornamentation of the traditional mosques.

TBMM Mosque among the other modern mosques has the lowest values in terms of sense of aesthetics. Participants generally mentioned that TBMM Mosque structure cannot be perceived as a mosque from outside since it does not have a dome and minarets. Therefore, participants evaluated the mosque architecture according to the classical mosque understanding. Since the design setup of the mosque is different from the other mosques, it was not found appropriate to the sense of a mosque. Moreover, not using the ornament elements in the design was evaluated as negative in terms of aesthetics.

When participants are categorized according to their age ranges it was found that design perceptions of academics regarding traditional mosques are more positive than their design perceptions regarding modern mosques. Only Şakirin Mosque was found closer to traditional mosque design. Even though positive perceptions of students regarding traditional mosques are higher, their comments regarding modern mosques were more positive in proportion to academics.

Designs of modern mosques are based on traditional mosques' design approaches however by means of technological innovations modern materials are used and different forms are pursued. But this pursuit sometimes has created a negative perception. Minbar, minaret and altar 
which are elements of traditional mosques are used in modern mosques in very different forms, colors and materials but there is a plainer and more modest design construct. And this construct affects users' classical mosque conception in a negative way.

Consequently; the style that the mosque architecture gained during the Ottoman Period reached the top and it has become the heritage of Ottoman Civilization. The reason why the new and contemporary design seeking for the mosque architecture in our day did not reach the desired levels is the admiration to the Ottoman style. Building mosques by imitating the classical mosque designs which were constructed centuries ago without adding anything on it is a situation which should be discussed. It should be believed that mosques are required to have an original design, their constructions should be based on the modern and contemporary building technology and the sense of classical mosques can be construed with modern designs. The number of innovative mosque design examples is very low. However, integrating the contemporary, modern and innovative mosque designs with the teachings obtained from the traditional mosques which are the expression of the existence and power of Islam by using technologic materials should not be considered as losing the features of mosques such as being socially open to everyone, being a place where people pray and being a tidied, humanitarian and spiritual place. At the same time, the sense of modern mosque design understanding should be free from the mosque constructions of which classical qualifications are lost just to be able to contemporary.

\section{REFERENCES}

[1] Akar, Z., "Spatial Analysis of Republican Mosque", Technical University of Karadeniz, Science İnstitute, The Main Disciplines of Architecture, Master's Thesis, Trabzon. 2004.

[2] Akok, M. "Interior Architecture of Turkish Mosques at XIII-XVII. Century" First International Congress of Turkish Art ,Ankara 19-24 October 1959, T.T.K. Printing House, Ankara, p. 16. 1962

[3] Aslanapa, O., Ottoman Period Architecture, Revolution Bookstore Publications, İstanbul, 568p. 1986

[4] Aydınlı, S., "Model-Based Spatial Perceptual Judicial Review", PHD Thesis,, Technical University of İstanbul, p 29-30, İstanbul. 1986.
[5] Çamlıbel, N., "Analytical Investigation of Building Structures in Sinan's Architecture", Technical University of Y1ldız publishing and printing center, 1998.

[6] Çinici, B.,. İmprovisation in Architecture and Behruz Çinici, Boyut Publication, İstanbul, 175p. 1999.

[7] Diez, E., "Minaret", Islamic Encyclopedia. C. VIII, İstanbul., p. 324, 1960.

[8] Erengezgin, Ç., “,Preface to Mosque As A Prayer Space” Architect, number:472, p.13-17. 2000.

[9] Eyüpgiller K. K., "Contemporary Mosque Architecture in 20th Century Mosque Architecture in Turkey" İTÜ Department of Architecture, Architecture 331, 2006.

[10] Holod R.-Khan, H., "The Mosque and the Modern World: Architects, Patrons and Designs Since the 1950's", London, 1997.

[11] İnci, N., “18. Century Mosque of Istanbul With Western Influence Innovations "Foundations Magazine, S. XIX, Sistem Offset, Ank., p. 223. 1985.

[12] Kazmaoğlu, A., "Contemporary Design and Technology At Architecture of Mosque From Tradition To Future", 1. National Mosque Architecture Symposium Proceedings, Religious Affairs Publications, p: 295, Ankara.2012.

[13] Kuban, D,. "Interior Design of The Ottoman Religious Architecture", İTÜ. Faculty of Architecture Publication, İstanbul, 1958.

[14] Kuban, D., "Şakirin Mosque and Design of Modern Mosque", Structure Magazine, number 333, August, 2009.

[15] Kuran, A., "Center Plan Concept at Turkish Mosque and Architect Sinan", I. Kayseri Culture and Art Week Speeches and Papers, Kayseri Municipality and Union Special Administrative Publications, Kayseri, 3: 6, 1987.

[16] Ödekan, A.,. “Article Mosque”, (D.HASOL editor). Eczacibaş1 Art Encyclopedia 1.Volume, YEM Publications, İstanbul, p: 316-319. 2000.

[17] Öz, T. Mosques of .İstanbul (1-2. Volume), Turkish Historical Society Publications, Ankara, 500 p, 1997.

[18] Özer, B., "Pluralism As A Representative Mimar Sinan Of The Mosque Architecture", Structure-75, p. 27-52, October. 1987.

[19] Ülgen, A., "Location of the Classical Ottoman Mosque Minaret", Marmara University, PHD Thesis, 1993.

[20] Tümer, G., ,'From Freak Mosques to Other Mosques Mea Architectura- Mea Culpa ", Architecture, number.331, Ankara, p. 31-38. 2006.

[21] Yilmaz, H., "Education Function of Mosques", Values Education Center Publications, İstanbul, , p. 18., 2005. 